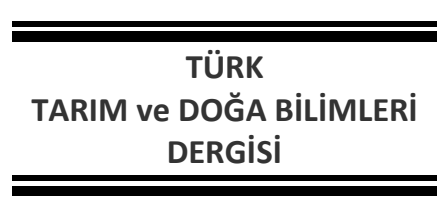

\section{Effect of Moringa, Thyme, Sumac Powders and Their Mixture on Growth Performance in Broiler Chicken ${ }^{*}$ \\ Research Article}

JOURNAL of AGRICULTURAL

and NATURAL SCIENCES

www.dergipark.gov.tr/turkjans
TURKISH

\author{
Bünyamin SÖĞÜT*, Amed Mohammed Ameen MOHAMMAD \\ Bingol University, College of Agriculture Department of Animal Science, Bingol, TURKEY \\ *Corresponding author: bunyaminsogut@hotmail.com
}

\begin{abstract}
Received: 13.06 .2018
Received in Revised: 08.07.2018

Accepted: 08.07.2018

Abstract

This study was conducted to figure out the effect of $1 \%$ inclusion of three herbal (Moringa leaves powder, Sumac fruit powder, Thyme powders and their mixture) in the diet on broiler chick's growth performance. A total of 181 a day-old male broiler chicks (Ross 308) were randomly distributed into five dietary treatments with 3 replicates (12 birds/rep). The groups were Control (no addition, T1), 1\% Moringa (Moringa oleifera) leaves powder (MLP, T2), 1\% Sumac (Rhus coriaria L.) fruit powder (SFP, T3), 1\% Thyme (Thymus vulgaris L.) leaves powder (TLP, T4), 1\% Mixture of Moringa, Sumac and Thyme leaves powder (MST, T5). The birds were offered non-pelleted diets ad libitum from beginnig to end of the trail. Live body weight, body weight gain, accumulative feed intake and feed conversion ratio were recorded weekly. Moringa leaves powder (MLP), Sumac fruit powder (SFP), the mixture of Moringa, Sumac and Thyme (MST) had significant $(p<0.05)$ effects on growth performance. Dietary supplementation of the herbs had positive effect on live body weight (LBW) and feed conversion ratio. The highest LBW was observed in MLP and MST groups. In terms of LBW, however, there was no significant $(p<$ 0.05) differences for the birds fed with supplemented Thyme leaves powder (TLP) relative to the control group during all total periods (0-42 d). Positive effects was observed on accumulative FCR comparing to the control group and the best significant FCR was obtained by using Moringa additive. However, there were no significant effects $(P<0.05)$ of treatments on accumulative feed intake except the feed supplementation with Thyme only when comparing to control group and other treatments. As a result, Moringa leaves powder, Sumac fruit powder, Thyme leaves powder, and Mixture of Moringa, Sumac \& Thyme leaves powder could be used as growth promoter instead of antibiotics by $1 \%$ of supplementation in the diet of broiler with no negative effects.
\end{abstract}

Key words: Broiler, moringa, sumac, thyme, feed performance.

\title{
Moringa, Kekik, Sumak Tozları ve Karışımının Etlik Piliçlerin Besi Performansı Üzerine Etkisi
}

\section{Özet}

Bu çalışma, üç tıbbi aromatik bitkinin (moringa yaprak tozu, sumak meyve tozu ve kekik yaprak tozu) ve bunların karışımları) \%1 oranında rasyona ilavesinin etlik piliçlerin besi performansına etkisini araştırmak amacıyla yürütülmüştür. Toplam yüz seksen adet bir günlük erkek broyler civcivleri (Ross 308), 3 tekerürlü beş gruba şansa bağlı olarak dağıtılmıştır. Gruplar; Control (T1), \%1 Moringa (Moringa oleifera) tozu (T2), \%1 Sumak (Rhus coriaria L.) meyve tozu (T3), \%1 Kekik (Thymus vulgaris L.) tozu (T4) ve \%1 Moringa, Sumak ve Kekik Karışımı tozu (T5) olarak belirlenmiştir. Deneme boyunca hayvanlara rasyon toz formunda adlibitum olarak verilmiştir. Canlı ağırlık, canlı ağılık artışı, yem tüketimi ve yemden yararlanma haftalık olarak kaydedilmiştir. Moringa tohumları (T2), Sumak meyve tozu (T3) ve Moringa, Sumak ve Kekik karışımı (T4) broiler civcivlerdeki canlı ağırlık ve yem dönüşüm oranı üzerinde önemli $(P<0.05)$ ve pozitif etkilere sahip olmuştur. Ayrıca, deneme süresinde kontrol grubuna kıyasla, muamele gruplarında yemden yaralanma oranı daha iyi olduğu tespit edilmiştir. Moringa ilavesinin yem tüketimi üzerine önemli bir etkisi ( $P>0.05$ ) görülmemiştir. Kontrol grubuna ve diğer muamele gruplarına kıyasla k-Kekik yaprek tozunun yem tüketimine etkili olduğu görülmüştür. Sonuç olarak, ticari broyler 
rasyonunda antibiyotik yerine büyüme faktörü olarak tek başına Moringa oleifera veya bitki karışımının (Moringa, Sumak ve Kekik) kullanılmasının büyüme ve gelişme özellikleri üzerine herhangi bir olumsuz etkisi olmadan rasyona katılabileceği anlaşılmıştır.

Anahtar kelimeler: Broiler, moringa, sumak, kekik, besi performansı.

\section{Introduction}

Chicken production considers one of the most commonly animal production species in developed countries. World Health Organization (WHO) recommended animal protein intake of $60 \mathrm{gm}$ per day is hardly met. It has been reported that, the cost of feed represents up to $60-80 \%$ of the total cost of broiler chicks production (Teguia and Beynen, 2005), accounts of feed cost for up to $80 \%$ of the total cost of production and is a very important component to finding out the extent of poultry survival and then profitability. Unremitting use of antibiotics in poultry may result in remainder effects in poultry products which may make the bacterial resistance against treatments in human body. Because of these disadvantage effects to human health, European Union since 2006 use of antibiotics in poultry was completely banned (Catala-Gregori et al., 2008). At present prevalent infectious diseases is the major trouble to the whole world which causes the financial failure to the poultry farmers. Also other factors like vaccination failure, infection by immune-oppressive diseases, and using antibiotics with the poor experience can cause deficiency in animal immunity. various alternatives to these antibiotic growth promoter replacements have been proposed to used such as organic acids and medicinal plants as natural feed additives are now recently used in poultry nutrition to improve the performance of the immune response of birds (Lee et al., 2003).

The medical plants have been the motif of stupendous scientific investigation. Due to present a number of pharmacologically effective materials, become to have a field for growth increment of livestock, they are supposed to promote activate digestive enzymes, stimulate immune and feed intake (Lee et al., 2003; Inci et al. 2015a; 2015b; Inci et al., 2016; Aydın and Alçiçek, 2017). There is a needed to innovation more efficient alternatives or blending of various alternatives to maintaining health and amendment the performance of poultry and other livestock (Fritz et al., 1993; Sogut et al., 2012; Aydın and Alçiçek, 2018). Some authors reported a significant positive effects on broiler performance (Ertas et al., 2005). Another group of authors reported no effect on gain, feed conversion or feed intake (Cross D.E et al., 2007).

Thyme (Thymus vulgaris) contain the main phenolic components Thymol (5-methyl-1-2isopropyl phenol) and carvacrol (5-isopropyl-2- methyl phenol). Thymus vulgaris species has special functions such as antimicrobial, antioxidant, expectorant, antispasmodic and antiseptic (AbuDarwish et al., 2009). Performance promoting influences of extract, essential oil, powder or principal components of thyme have been demonstrated in poultry (Lee et al., 2003). There was an influence of dietary supplemental plant extracts on digestive system development, intestinal microflora of broiler chicks carcass characteristics, performance and some blood parameters (Tekeli et al., 2006).

Sumac (Rhus coriaria L.) used as a spice and with the long history of use by indigenous people as medicinal plant, and other applications. The fruits of sumac contain hydrolysable tannins, flavonols, phenolic acids, anthocyans and organic acids such as malice, citric and tartaric acids (Özcan and Haciseferogullari, 2004).

Moringa oleifera tree, from the roots to the leaves has beneficial properties. Various parts of which are used as fodder, spices, herbal medicine, food, natural coagulants, fertilizer, nectar for bees and fuel. Moringa contains very high antiinflammatory and antioxidants compounds (Yang et al., 2006). The leaves, flowers and pods are used as better sources of vitamins A, B and C, folic acid, ascorbic acid, nicotinic acid, riboflavin, pyridoxine, beta-carotene, iron, calcium, and alpha-tocopherol. The pods are considered as an interest source of the essential amino acids. A compound, pterygospermin found in the flowers and roots of the Moringa has strong fungicidal and antibiotic effects (Das et al., 1957). The leaves of Moringa oleifera have increase immunity in broilers. Thus, leaf meal from both Moringa oleifera and Moringa stenopetala might be good feed additives in livestock production, (Du et al., 2007).

The effect of $1 \%$ inclusion of three herbal (Moringa leaves powder, Sumac fruit powder, Thyme powders and their mixture) in the diet on broiler chick's growth performance was the subject of this study.

\section{Material and Methods}

According to the ingredient composition, based broiler starter, grower and finisher were formulated by Local feed manufacturers company in Bingol city in Turkey. Moringa oleifera leaf 
powder (MLP) was acquired from online market of Herbal natural international company in the United States, and original of plant from India. Sumac fruit powder (SFP) from our orchard in Dohok-Akre city in Iraq and Thyme leaf powder (TLP) was acquire from Mardin city in Turkey. All herbal plants were purchased as dried grinded and fine powders, and they were analyzed in University central laboratory, University of Bingol, by instrument called Gas Chromatography/Mass Spectrometry (GC-MS), to determine active compounds in all of Moringa, Sumac and Thyme.

A total of 181 a day-old male broiler chicks (Ross 308) strain, were purchased from a commercial hatchery in Turkey. And they were weighed and assigned into five dietary treatments in a complete randomized design. On arrival, they were randomly distributed into five dietary treatments, and each treatment was divided into three replicates with 12 chicks per replicate. Moringa, Sumac and thyme as powders were added to the diet at $7^{\text {th }}$ day of age. The birds offered nonpelleted diets ad libitum, starter, grower and finisher diets were offered from 7 to 21 days, from 22 to 35 days and from 36-42 days, respectively, and clean water be provided throughout the period of the experiment. Experimental diets were starter, grower, and finisher, with all of them in nonpelleted form. A starter diet was offered to birds during the period of 7-21 days and included \%23 crude protein (CP) and $3150 \mathrm{kcal} / \mathrm{kg} \mathrm{ME;} \mathrm{a} \mathrm{grower}$ diet was offered from 22-35 days and included \% 21 $\mathrm{CP}$ and $3200 \mathrm{kcal} / \mathrm{kg} \mathrm{ME}$; and a finisher diet was offered from 36-42 days and included \% 19 CP and $3200 \mathrm{kcal} / \mathrm{kg} \mathrm{ME}$. Before to beginning of addition of herbs plants (up to 7 days of age), all chicks were fed on a starter diet. This study was initiated at 7 days of age. Five dietary treatments namely Control (No addition, T1), 1\% Moringa (Moringa oleifera) leaves powder (MLP, T2), 1\% Sumac (Rhus coriaria L.) fruit powder (SFP, T3), 1\% Thyme (Thymus vulgaris L.) leaves powder (TLP, T4), 1\% Mixture (Moringa, Sumac \& Thyme) leaves powder (MST, T5).

The birds were kept in a deep litter housing system at concrete floor. Wood shavings or sawdust were used as litter at a $5 \mathrm{~cm}$ in depth. Before use the house, cages, drinkers, and feeders and all equipment, they were cleaned and disinfected with suitable disinfectants before to the commencement of the experiment. Heating was provided by electrical heaters, where the initial ambient temperature was set at $33 \mathrm{C}^{\circ}$ and was gradually decreased by $2.5 \mathrm{C}$ approximately per week to final temperature of 23-22 $C$ at 21 day of age then continued till the end of experiment. Chicks were leg-tagged and body weight and feed intake were taken at the beginning of the experiment and subsequently on a weekly. Weight gain, feed conversion ratio and feed efficiency ratios were calculated.

Grow performance characteristics include; weekly and final live body weight, body weight gain, feed intake level, feed conversion ratio.

\section{Statistical analysis}

All data were subjected to statistical analysis as per standard methods. Statistical analysis SAS (2005) was used to analyze the data to account the effects of treatments. The Duncan's multiple range tests was used to test the significance between means.

\section{Results and Discussion Live body weight}

In the present study, the effects of herbal feed additives on live body weight of broiler chicks during 7-42 days of age period were presented in Table 2. The diets with herbal feed additives improved the live body weight generally. At the end of experiment (42 d), the highest (2479.7 live body weight (LBW) were observed in 12 group which was significantly $(p<0.05)$ different than control. Besides, treatment groups (T2, T3 and T5) had higher LBW than control. Additives of $1 \%$ thyme leaves powder did not alter the LBW significantly $(P>0.05)$ even though lower than control. The results indicated that live body weight with herbal feed additive for birds fed on T2 and T5 which containing Moringa leaves powder were significantly $(p<0.05)$ higher as compared to the control group.

The improving live body weight of chick fed with Moringa leaves powder could be attributed to high digestibility of Moringa leaves (Becker, 1995) which may enhance absorption of nutrients. This effect of Moringa leaves powder leads to higher LBW. These results were in agreement with the finding of Banjo (2012) who observed that the inclusion of Moringa oleifera leaf meal (MOLM) with $1 \%, 2 \%$ and $3 \%$ levels in diet of broilers significantly $(\mathrm{P}<0.05)$ improved LBW gain at $1 \%$ level, which was higher than the control significantly. In this accept, David et al. (2012) who used seven experimental diets consist of control, negative control, $0.0125 \%$ flavomycin (positive control), $0.05 \%$ Moringa leaf powder, $0.1 \%$ Moringa leaf powder, $0.035 \%$ Zigbir (commercial herbal product), $0.05 \%$ Moringa fruit powder (MFP) and $0.1 \%$ Moringa fruit powder (MFP). The study exposed that all selected additive dietary supplements significantly $(P<0.05)$ enhance the growth performance of birds compared to the 
negative control. Moreover, the body weight gain of birds were increased with the increasing levels of both Moringa leaf and fruit powder during the finisher and total periods. Also, Teteh et al. (2013) observed that all chick LBW and daily body weight gain increased significantly $(\mathrm{P}<0.05)$ compared to the control group when used $1 \%$ and $2 \%$ Moringa oleifera leaf meal (MOLM). On the other hand, Nkukwana et al., (2014) applied MOLM low (ML; 1, 3 and 5g); (MOLM) medium (MM; 3, 9 and $15 \mathrm{~g}$ ); (MOLM) high (MH; 5, 15 and $25 \mathrm{~g}$ )/ kg of feed, and a negative control. Chicks fed $\mathrm{MH}$ had the highest LBW. Along the same line, Karthivashan et al. (2015) showed that fed on $0.5 \%, 1.0 \%$ and $1.5 \%$ of MOLM extracts significantly $(P<0.05)$ enhanced weight gain compared to control group, while there were no significant differences in weight gain for the dietary treatments with MOLM. On the contrary, Makanjuola et al., (2014) pointed that adding $0.2,0.4$ and $0.6 \%$ of MOLM to the feed, lasted 28 days, had no adverse influence on final weight and BWG in broiler chicken. Also Paguia et al., (2014) observed that using 0.20, 0.30, 0.40 and $0.50 \%$ of MOLM in the diet of broiler chicks did not $(P<0.05)$ significantly affect the broilers BW and BWG.

Table 1. Composition and ingredients of broiler diets.

\begin{tabular}{|c|c|c|c|}
\hline Ingredient (g) & Starter & Grower & Finisher \\
\hline Maize, yellow & 355.5 & 330.4 & 256.8 \\
\hline Soybean meal (480 g CP kg*) & 275.3 & 204.5 & 171.5 \\
\hline Sunflower meal (350 g CP kg*) & 110.0 & 150.0 & 111.5 \\
\hline Wheat & 99.0 & 130.0 & 330.0 \\
\hline Wheat bran & - & 38.0 & - \\
\hline Meat-bone meal & 64.4 & 56.0 & 49.2 \\
\hline Vegetable oil & 73.7 & 85.0 & 73.6 \\
\hline Limestone & 13.6 & - & - \\
\hline Premix1 & 3.5 & 3.5 & 3.1 \\
\hline Sodium chloride & 3.0 & 2.5 & 2.5 \\
\hline L-lysine & 0.4 & - & 0.1 \\
\hline DL-methionine & 1.6 & 0.1 & 1.7 \\
\hline \multicolumn{4}{|c|}{ Chemical composition (g kg* as fed) } \\
\hline ME (Mcal/kg of diet) & 3.15 & 3.20 & 3.20 \\
\hline Crude protein & 230.0 & 212.0 & 189.8 \\
\hline Calcium & 15.0 & 9.0 & 8.0 \\
\hline Available phosphorus & 5.0 & 4.7 & 3.9 \\
\hline Lysine & 12.0 & 10.0 & 8.5 \\
\hline Methionine & 5.6 & 4.0 & 5.2 \\
\hline Methionine + cysteine & 9.3 & 7.6 & 8.4 \\
\hline Sodium chloride & 3.4 & 2.9 & 2.9 \\
\hline
\end{tabular}

CP: Crude protein; ME: Metabolizable energy. *Provides per kilogram of diet: Mn, 80 mg; Zn, 60 mg; Fe, 60 mg; $\mathrm{Cu}, 5 \mathrm{mg}$; Co, $0.2 \mathrm{mg}$; I, $1 \mathrm{mg}$; Se, $0.15 \mathrm{mg}$; choline chloride, $200 \mathrm{mg}$; vitamin A, 12,000 IU; vitamin D3, 2,400 IU; vitamin E, $50 \mathrm{mg}$; vitamin K3, $4 \mathrm{mg}$; vitamin B1, $3 \mathrm{mg}$; vitamin B2, $6 \mathrm{mg}$; niacin, $25 \mathrm{mg}$; calcium-D-pantothenate, $10 \mathrm{mg}$; vitamin B6, $5 \mathrm{mg}$; vitamin B12, $0.03 \mathrm{mg}$; D-biotin, $0.05 \mathrm{mg}$; and folic acid, $1 \mathrm{mg}$.

Table 2. The effect of medical plants powders on live body weight $(\mathrm{g})$ of broilers at different period.

\begin{tabular}{ccccccc}
\hline \multicolumn{7}{c}{ Body weight (g) at different time (day) } \\
\hline T1 & $180.1 \pm 4.7^{\mathrm{a}}$ & $376.6 \pm 10.5^{\mathrm{a}}$ & $750.6 \pm 27.3^{\mathrm{b}}$ & $1168 \pm 35.1^{\mathrm{b}}$ & $1660.5 \pm 59.8^{\mathrm{a}}$ & $2275 \pm 58.5^{\mathrm{ab}}$ \\
T2 & $182.6 \pm 4.7^{\mathrm{ab}}$ & $449.5 \pm 10.5^{\mathrm{c}}$ & $894.4 \pm 27.3^{\mathrm{c}}$ & $1371.5 \pm 35.1^{\mathrm{c}}$ & $1875.2 \pm 59.8^{\mathrm{b}}$ & $2479.7 \pm 53.2^{\mathrm{c}}$ \\
T3 & $193.4 \pm 4.7^{\mathrm{b}}$ & $431.5 \pm 10.5^{\mathrm{bc}}$ & $841 \pm 27.3^{\mathrm{c}}$ & $1211.5 \pm 35.1^{\mathrm{b}}$ & $1811 \pm 59.8^{\mathrm{ab}}$ & $2387.3 \pm 55.2^{\mathrm{bc}}$ \\
T4 & $187.5 \pm 4.7^{\mathrm{ab}}$ & $404 \pm 10.5^{\mathrm{ab}}$ & $649 \pm 27.3^{\mathrm{a}}$ & $911.3 \pm 35.1^{\mathrm{a}}$ & $1665.7 \pm 59.8^{\mathrm{a}}$ & $2194.5 \pm 59.8^{\mathrm{a}}$ \\
T5 & $184.1 \pm 4.7^{\mathrm{ab}}$ & $447.6 \pm 10.5^{\mathrm{c}}$ & $887.5 \pm 27.3^{\mathrm{c}}$ & $1392.4 \pm 35.1^{\mathrm{c}}$ & $1960.3 \pm 59.8^{\mathrm{b}}$ & $2436.7 \pm 52.3^{\mathrm{c}}$ \\
\hline
\end{tabular}

T1= Control (No addition). T2= Moringa leaves powder 1\%. T3= Sumac fruit powder 1\%. T4= Thyme leaves powder $1 \%$. T5= Mixture Moringa, Sumac \& Thyme 1\%. a, b, c= Means between treatments having different letters in same column are significant $(p<0.05)$.

The higher weight in the chicks fed MLP diets in T2 may be partly due to a good protein quality, perhaps arising from a higher methionine and lysine provide (Booth and Wickens, 1988). Vitamin A is 
necessary for growth. MLP was reported to have a high Vitamin A (Booth and Wicken, 1988; Grubben and Denton, 2004; Fuglie, 2005). The control treatment might have provided insufficient Vitamin $A$, therefore resulting in poor growth since Vitamin A to promoting growth. Pond et al. (1995) stated that Vitamin A insufficiency in the diets makes the rabbits to exhibit poor growth. Our collections established that addition of sumac fruit powder (SFP) at level of $1 \%$ for broiler led to significant $(p<$ $0.05)$ differences on the live body compared to the control group. Mansoob (2012), showed that using different levels sumac had significant effects on weigh enhancement, average of weight and feed conversion ratio of broiler chicks $(P<0.05)$. The enhancement of body weight gain and feed conversion ratio may be because of the active materials (cinnamaldehyde and ugenol) present in sumac, inducing higher efficiency in the utilization of nutrition, resulting in improved growth (Lee et al., 2003). The present of Phenolic compounds in sumac inhibit lipid peroxidation, scavenge the hydroxyl radical and superoxide anion (Jung, 1998, Khalaf et al., 2008) and increase the activities of detoxifying enzymes like glutathione-S-transferase (Mazloom, 2011). D-limonene (I-methyl-4-(1methylethenyl)-cyclohexane) is a monocyclic mlonoterpene constituent of sumac that has hypocholesterolemic influences (Kurucu et al., 1993). Ahmadian-Attari et al. (2007) observed that use of sumac extract can enhance growth and have good effect on broilers. Rayne and Mazza (2007) showed that sumac extracts had antimicrobial, antioxidant and hypoglycemic activities and has led to better performance growth for broilers. Some herbal plants or specific combinations of herbs in preparations may act as antioxidants by exerting superoxide scavenging activity or by raising superoxide dismutase activity in various tissue sites (Weiner, 1994). Antimicrobial substances existing in sumac can decrease the harmful bacteria in the gastrointestinal tract and increase the levels of absorbed amino acids. Sumac contains polyphenolic components which may be causing the hypocholesterolemic action (Mansoob 2011).

Although it was awaited that supplementing the plant extracts (Lee et al., 2003; Demir et al., 2008) or additive herbs (Bampidis et al., 2005; Cross et al., 2003; 2007) could induce the growth performance of broilers. Plant extracts, essential oil and the main components of the essential oil afforded contradicting results (Alcicek et al., 2003, Acamovic and Broker, 2005; Griggs and Jacob, 2005; Bampidis et al., 2005). In present study of thyme $(1 \%$ TLP), there was no significant effect $(p<0.05)$ in terms of LBW comparing to control, these results were in agreement with some studies (Demir et al., 2008; Cross et al., 2003, 2007; Hernandez et al., 2004; Bampidis et al., 2005). Also Najafi and Torki (2010) reported that the low dosage $(5 \mathrm{~g} / \mathrm{Kg})$ of Thyme have significant effect on broiler chick LBW and their FCR, while the high dosage $(10 \mathrm{~g} / \mathrm{Kg})$ did not show this effect. The improvement of performance observed in broilers fed the mixture of dried thyme leaves powder with other herbs could be due to the enhancement of nutrient digestibility established in this study with the development of digestive organs. Reduce in crypt depth in the ileum of birds given dietary natural growth promoters, and conserved the energy by the decrease turnover rate of the epithelial cells made be utilized for lean tissue mass synthesis (Lilja, 1983).

\section{Feed intake (FI)}

The effect of $1 \%$ dietary supplementation of T2, T3, T4 and T5 on daily accumulative feed intake showed in Table 3. Broilers fed with T2, T3 and T5 were not affected significantly $(P>0.05)$ compared to the control in terms of $\mathrm{FI}$. On the other hand, $\mathrm{FI}$ was significantly affected $(\mathrm{P}<0.05)$ by Thyme leaves powder (T4) compared to the control and to all other treatments. The lowest FI was observed in T4.

As a discussion about feed intake, Banjo (2012) reported no significant differences in feed intake in broilers fed with levels of Moringa (1, 2 and $3 \%)$. Result of this study agreement in results of Soad (2010), who state that there was no significant differences $(P>0.05)$ in feed intake between the groups fed with $0,2,4$ and $6 \%$ of Moringa oleifera Leaf. This note was supported by the findings of Ravindran et al. (1983), in where feed intake and feed/gain raised as cassava leaf meal or dehydrated alfalfa meal leaf meals raised. On the other hand, Madubuike and Ekenyem (2006) reported enhanced feed intake for broilers fed diets with 5 and $10 \%$ levels of Moringa, however, $\mathrm{FI}$ was depressed at $15 \%$. This conforms to the observations established by Ash et al. (1992) that including of MOL meals in broiler diets about 5 to $10 \%$ results in depressed performance.

\section{Feed conversion ratio (FCR)}

The effect of $1 \%$ feeding dietary supplementation of T2, T4 and T5 on daily accumulative FCR of broilers was showed in Table 4. It was noted that average accumulative FCR was not affected by T2, T3 and T5 compared to the control at 0-14days and 0-21days of age. But it was significant $(p<0.05)$ in T4 comparing to the control and other treatments during all period of experiment. 
Table 3. Effect of the medicine plants powders on daily accumulative feed intake $(\mathrm{g})$ of broilers.

\begin{tabular}{cccccc}
\hline \multicolumn{5}{c}{ Time period (d) } \\
\hline Treatments & $0-14 d$ & $0-21 d$ & $0-28 d$ & $0-35 d$ & $0-42 d$ \\
\hline T1 & $439.13^{\text {ab }}$ & $978.43^{\mathrm{b}}$ & $1762.28^{\mathrm{b}}$ & $2915.30^{\mathrm{b}}$ & $4116.39^{\mathrm{b}}$ \\
T2 & $485.98^{\mathrm{bc}}$ & $1041.49^{\mathrm{b}}$ & $1820.30^{\mathrm{b}}$ & $2873.94^{\mathrm{b}}$ & $3883.05^{\mathrm{b}}$ \\
T3 & $545.02^{\mathrm{c}}$ & $1092.16^{\mathrm{b}}$ & $1789.77^{\mathrm{b}}$ & $2863.21^{\mathrm{b}}$ & $4050.19^{\mathrm{b}}$ \\
T4 & $385.48^{\mathrm{a}}$ & $724.75^{\mathrm{a}}$ & $1309.57^{\mathrm{a}}$ & $2934.65^{\mathrm{a}}$ & $3283.87^{\mathrm{a}}$ \\
T5 & $523.95^{\mathrm{b}}$ & $1078.78^{\mathrm{b}}$ & $1804.81^{\mathrm{b}}$ & $2254.29^{\mathrm{b}}$ & $3978.70^{\mathrm{b}}$ \\
\hline SEM & \pm 28.22 & \pm 35.14 & \pm 47.8 & \pm 69.4 & \pm 94.16 \\
\hline
\end{tabular}

T1= Control (No addition). T2= Moringa leaves powder 1\%. T3= Sumac fruit powder 1\%. T4= Thyme leaves powder $1 \%$. T5= Mixture (Moringa, Sumac \& Thyme) 1\%. Figure mean \pm standard deviation of chicks of treatment. $a, b, c=$ Means between treatments having different letters are significantly $(p<0.05)$.

At the interval of $\mathrm{T} 2(1 \% \mathrm{MLP})$ and $\mathrm{T} 5$ (1\%MST) at $0-28$ days, $0-35$ days and $0-42$ days of age, the FCR was recorded a significantly $(p<0.05)$ different compared to the control, and the best significant FCR (1.29) was obtained in group T5 at 0-28 days as comparing to control and other treatments. Mansoob (2011) demonstrated that using different levels sumac had significant $(P<0.05)$ effects on FCR of broilers, and this because of the active materials (cinnamaldehyde and ugenol) found in sumac, causing high efficiency in the utilization of feed, resulting the growth improvement. Lower FCR was observed in birds fed diets containing 5,10 and $15 \%$ of $\mathrm{MOL}$
(Iheukwumere et al., 2008) consistent with present findings. There was also differences of treatments on the cost of feed per $\mathrm{kg}$. The cost of feed reduced as more moriga oleifera replaced groundnut cake in the diets. The results are in agreement with the findings of studies (Al-Jugifi, 2009; Al-Mashhadani et al., 2011; Foroughi, et al., 2011) that using diet additive of thyme in broilers had a significant effect on the FCR compared to the control. Aromatic oil from thyme (Thymus vulgaris) was evaluated for antibacterial, antifungal and antiviral activity as inhibitors of microbial growth (Dorman and Deans, 2000). This phenomenon perhaps leads to increase the availability of fatty acids and hence, performance improvement.

Table 4. Effect of the medicine plants powders of daily accumulative feed conversion of broilers.

\begin{tabular}{cccccc}
\hline \multicolumn{7}{c}{ Time Period (d) } \\
\hline Treatments & $0-14 \mathrm{~d}$ & $0-21 \mathrm{~d}$ & $0-28 \mathrm{~d}$ & $0-35 \mathrm{~d}$ & $0-42 \mathrm{~d}$ \\
\hline T1 & $1.18^{\mathrm{b}}$ & $1.34^{\mathrm{a}}$ & $1.52^{\mathrm{b}}$ & $1.78^{\mathrm{b}}$ & $1.87^{\mathrm{c}}$ \\
T2 & $1.08^{\mathrm{ab}}$ & $1.16^{\mathrm{a}}$ & $1.32^{\mathrm{a}}$ & $1.53^{\mathrm{a}}$ & $1.63^{\mathrm{b}}$ \\
T3 & $1.26^{\mathrm{b}}$ & $1.29^{\mathrm{a}}$ & $1.47^{\mathrm{b}}$ & $1.58^{\mathrm{ab}}$ & $1.62^{\mathrm{b}}$ \\
T4 & $0.95^{\mathrm{a}}$ & $1.12^{\mathrm{a}}$ & $1.43^{\mathrm{b}}$ & $1.38^{\mathrm{a}}$ & $1.57^{\mathrm{a}}$ \\
T5 & $1.17^{\mathrm{b}}$ & $1.21^{\mathrm{a}}$ & $1.29^{\mathrm{a}}$ & $1.49^{\mathrm{a}}$ & $1.63^{\mathrm{b}}$ \\
\hline SEM & \pm 0.06 & \pm 0.07 & \pm 0.03 & \pm 0.07 & \pm 0.04 \\
\hline
\end{tabular}

$\mathrm{T} 1=$ Control (No addition). T2= Moringa leaves powder 1\%. T3= Sumac fruit powder 1\%. T4= Thyme leaves powder $1 \% . T 5=$ Mixture (Moringa, Sumac \& Thyme) $1 \%$. Figure mean \pm standard deviation of chicks of treatment. $a, b, c=$ Means between treatments having different letters are significantly $(p<0.05)$. N.S= The same superscripts within row of week indicate non-significant differences at $(p<0.05)$.

\section{Conclusion}

Results showed that there was a significant differences $(p<0.05)$ among the experimental groups. Medical plants powders in the diet of broilers, (MLP, SFP, and MST) had significant $(p<0.05)$ effects on broilers performance. They were recorded positive effect on LBW gain and FCR in broiler chicks, and with the highest body weight in (MLP) and (MST). However, dietary treatments of herbal plants powders in this study had no significant $(p<0.05)$ differences for birds fed on Thyme leaves powder (TLP) relative to the control group during all total periods (0-42) day of age. There were positive effects on accumulative FCR comparing to the control group during the experiment and the best significant FCR was obtained in the group fed by Moringa additive. However, FI was not affected by treatment except the feed supplementation with Thyme only when comparing to control group and other treatments.

$¥:$ This manuscript was produced from Amed Mohammed Ameen MOHAMMAD's master's thesis. 


\section{References}

Abu-Darwish, M., Dieyeh, Z.H., Al-Tawaha, A.R.M., Batarseh, M. 2009. Trace element contents and essential oil yields from wild thyme plant (Thymus serpyllum L.) grown at different natural variable environments, Jordan. Journal of Food Agriculture and Environment, 7(3\&4): 920-924.

Acamovic, T., Brooker, J.D. 2005. Biochemistry of plant secondary metabolites and their effects in animals. Proc. Nutr. Soc. 64; 403.

Ahmadian-Attari, M., Amin, G.H., Fazeli, M.R., Jamalifar, H. 2007. A review on the antibacterial and effects of sumac fruit. Medicinal Plants, 7 (1): 1-9.

Alcicek, A., Bozkurt, M. Cabuk, M. 2003. The effect of an essential oil combination derived from selected herbs growing wild in turkey on broiler performance. South African Journal of Animal Science, 33: 89-92.

Al-Jugifi, W.I.K. 2009. Effect of different levels of Thyme vulgaris on performance of broiler chicken. Al-Anbar Journal of Veterinary Sciences, 2(1): 111-120.

Al-Mashhadani, E.H., Farah, K., Al-Jaff, Y.M. Farhan 2011. Effect of anise, thyme essential oils and their mixture (EOM) on broiler performance and some physiological traits. Egyptian Poultry Science, 31(2): 481-489.

Ash, A.J., Petaia, L., Ako, H. 1992. Nutritional value of Sesbania grandiflora leaves for monogastric and ruminants. Tropical Agriculture (Trinidada), 69(3).

Aydın, A., Alçiçek, A. 2018. Effects of the supplementation of essential oil isolated from orange peel (Citrus sinensis L.) to broiler diets on the performance. Turkish Journal of Agricultural and Natural Sciences, 5(2): 127-135, 2018-128.

Aydın, A., Alçiçek, A., 2017. Effects of essentıal oil supplementation isolated from orange peel (Citrus sinensis L.) tobroiler diets on the performance. I. Internetional Congress of Medicinal and Aromatic Plants. Book of Abstracts, p.558. Konya.

Bampidis, V.A., Christodoulou, V., Florou-Paneri, P., Christaki, E., Chatzopoulou, P.S., Tsiligianni, T., Spais, A.B. 2005. Effect of dietary dried oregano leaves on growth performance, carcass characteristics and serum cholesterol of female early maturing turkeys. Brit. Poult. Sci., 46: 595-601.

Banjo, S. (2012). Growth and performance as affected by inclusion of Moringa oleifera leaf meal in broiler chick diet. J. Biol. Agric. Healthcare. 2(9): 35-38.
Becker, K. 1995. Studies on Utilization of Moringa oleifera Leaves as Animal Feed. Institute for Animal Production in the Tropics and Subtropics vol. 480. University of Hohenheim Stuttgart, p.15.

Booth, F.E.M., Wickens, G.E. 1988. Non-Timber Uses of Selected Arid Zone Trees and Shrubs in Africa. FAO Conversation Guide, Rome, pp. 92-101.

Catalá-Gregori, P., Mallet, S., Travel, A., Lessire, M. 2008. Efficiency of a Prebiotic and a Plant Extract on Broiler Performance and Intestinal Physiology. 16th European Symposium on Poultry Nutrition, World Poultry Science Association, Strasbourg, France.

Cross, D.E., Mcdevitt, R.M., Hillman, K., Acamovic, T. 2007. The effect of herbs and their associated essential oils on performance, dietary digestibility and gut microflora in chickens from 7 to 28 days of age. Br. Poult. Sci., 48: 496-506.

Cross, D.E., Svoboda, K., McDevitt, R.M., Acamovic, T. 2003. The performance of chickens fed diets with and without thyme oil and enzymes. Br. Poult. Sci., 44(supp1): 18-19.

Das, B.R., Kurup, P.A., Rao, P.L.N. 1957. Antibiotic principle from Moringa pterygosperma: VII. Antibacterial activity and chemical structure of compounds related to pterygospermin. India J. Med. Res., 45: 191-196.

David, L.S., Vidanarachchi, J.K., Samarasinghe, K., Cyril, H.W., Dematawewa, C.M.B. 2012. Effects of moringa based feed additives on the growth performance and carcass quality of broiler chicken. Tropical Agricultural Research, 24(1): 12-20.

Demir, E., Kilinc, K., Yildirim, Y., Dincer, F., Eseceli, H. 2008. Comparative effects of mint, sage, thyme and flavomycin in wheat- based broiler diets. Archiva Zootechnica, 11(3): 5463.

Dorman, H.J.D., Deans, S.G. 2000. Antimicrobial agents from plants: Antimicrobial activity of plant volatile oils. Journal of Applied Microbiology, 88: 308-316.

Du, P.L., Lin, P.H., Yang, R.Y., Fan, Y.K., Hsu, J.C. 2007. Effects of dietary supplementation of Moringa oleifera on growth performance, blood characteristics and immune response in broilers. Journal of the Chinese Society of Animal Science, 36(3): 135-146.

Ertas, O.N., Guler, T., Çiftci, M., Dalkilic, B., Simsek, Ü.G. 2005. The effect of an essential oil mix derived from oregano, clove and anise on broiler performance. In. J. Poult. Sci., 4: 879884. 
Foroughi, A.R., Torghabeh, H.M., Salen, H. 2011. The effect of essential oil of thyme (thyme vulgaris) on performance and humoral immune response broiler chicken. Agricultural Journal, 6(6): 299-302.

Fritz, Z., Schleicher, A., Kinal, S. 1993. Research on the use of herbal mixtures in broiler diets has produced inconsistent results. J. Anim. Feed Sci., 2: 189-195.

Fuglie, L.J. 2005. The Miracle Tree: The Moringa Tree: A Local Solution to Malnutrition. Natural Nutrition for the Tropics. Church World Service, Dakar, 68 pp.

Griggs, J.P., Jacob, J.P. 2005. Alternatives to antibiotics for organic poultry production. J. Appl. Poult. Res., 14: 750-756.

Grubben, G.J.H., Denton, O.A. 2004. Plant Resources of Tropical Africa. Vegetables. PROTA Foundation, Wageningen, Netherlands/ backhuys Publishers, Leiden, Netherlands/ CTA, Wageningen Netherlands.

http://www/hort.purdue/edu/newcrop.duk e_energy/moringa.htm.

Hernandez, F., Madrid, J., Garcia, V., Orengo, J., Megi'as, M.D. 2004. Influence of two plant extracts on broilers performance, digestibility, and digestive organ size. Poult. Sci., 83: 169-174.

Iheukwumere, F.C., Ndubuisi, E.C., Mazi, E.A., Onyekwere, M.U. 2008. Performance, nutrient utilization and organ characterstics of broilers fed cassava leaf meal (Manihot esculenta Crantz). Pakistan Journal of Nutrition, 7(1): 13-16.

Inci H, Celik S, Sogut B, Sengul T and Karakaya E. 2015a. Examining the effects of different feather colour on the characteristics of interior and exterior egg quality of Japanese quail by using Kruskal-Wallis Test. Türk Tarım ve Doğa Bilimleri Dergisi 2(1): 112-18.

Inci, H., Şengül, AY., Daş, A., Karakaya, E., Kayaokay, A. 2015b. Kafes ve Yer Sisteminde Yetiştirilen Bıldırcınların Besi Performansı ve Karkas Özellikleri Bakımından Karşılaştırılması. Türk Tarım ve Doğa Bilimleri Dergisi 2(1): 119125.

Inci, H., Özdemir, G., Şengül, A.Y., Söğüt, B., Nursoy, H., Şengül, T. 2016. Using juniper berry (Juniperus communis) as a supplement in Japanese quail diets. R. Bras. Zoolec., 5(5): 230-235.

Jung, N.C. 1998. Biological Activity of Urushiol and Flavanoid from Lac Tree (Rhus verniciflua Stokes). Ph.D. Thesis Chonnam National University, Kwang-Ju, South Korea.
Karthivashan, G., Arulselvan, P., Alimon, A., Ismail, I.S., Sharida Fakurazi, S. 2015. Competing Role of Bioactive Constituents in Moringa oleifera Extract and Conventional Nutrition Feed on the Performance of Cobb 500 Broilers. BioMed Research International. Article ID 970398, 13 p., N.

Khalaf, A.N., Shakya, A.K., Al-Othman, A., El-Agbar, Z., Farah, H. 2008. Antioxidant activity of some common plants. Turkish J. Biol., 32: 5155.

Kurucu, S., Koyuncu, M., Guvenc, A., Baser, K.H.C., Ozek, T. 1993. The essential oil of Rhus coriaria L. (sumac). J. Essent. Oil Res: Jeor., 5: 481-486.

Lee, K.W., Everts, H., Kappert, H.J., Frehner, M., Losa, R., Beynen, A.C. 2003. Supposed to presence of a number of pharmacologically active substances which stimulate immune, activate digestive enzymes and enhance feed intake. Brit. Poultry Sci., 44: 450-457.

Lilja, C., 1983. Comparative study of postnatal growth and organ development in some species of birds. Growth, 47: 317-329.

Madubuike, F.N., Ekenyem, B.U. 2006. Haematology and serum biochemistry characteristics of broiler chicks fed varying dietary levels of Ipomoea asarifolia leaf meal. Int. J. Poult. Sci., 5: 09-12.

Makanjuola, B.A., Obi, O.O., Olorungbohunmi, T.O., Morakinyo, O.A., Oladele-Bukola, M.O., Boladuro, B.A. 2014. Effect of Moringa oleifera leaf meal as a substitute for antibiotics on the performance and blood parameters of broiler chickens. Livestock Researchfor Rural Development 26(8).

Mansoob, H.N. 2012. Effect of different levels of sumac powder (Rhus coriaria L.) on performance, carcass and blood parameters of broiler chickens. Annals of Biol. Res., 2(5): 647-652.

Mansoob, N.H., Myandoab, M.P. 2011. The effect of different levels of thyme on performance, carcass traits and blood parameters of broilers. Annals of Biological Research, 2(4): 379-385.

Mazloom, Z.F. 2011. Influence of garlic and sumac powder (Rhus coriaria L.) on performance, carcass and blood biochemical's of Japanese quails. Annals of Biol. Res., 2(6): 542-545.

Najafi, P., Torki, M. 2010. Founded that fed by thyme had significantly better body weight and feed conversion ratio. Journal of Animal and Veterinary Advances, 9(7): 1164-1168.

Nkukwana, T., Muchenje, M., Masika, P.J., Dzama, K. 2014. Proximate composition and variation in colour, drip loss and $\mathrm{pH}$ of breast 
meat from broilers supplemented with Moringa oleifera leaf meal over time. Animal Production Science, 55(7).

Özcan, M., Haciseferogullari, H. 2004. A condiment sumac (Rhus coriaria L.) fruits: Properties. Bulg. J. Plant Physiol., 30: 74-84.

Paguia, H.M., Paguia, R.Q., Flores, R.C., Balba, C.M. 2014. Utilization and Evaluation of Moringa oleifera as Poultry Feeds. Monograph No. 11. The Research and Developmet Office, Bataan Peninsula State University City of Balanga, Philippines.

Pond, W.G., Church, D.C., Pond, K.R. 1995. Basic Animal Nutrition and Feeding. 4th Edition John Wiley and Sons Publication, New York USA pp. 495-504.

Ravindran, V., Kornegay, E.T., Cherry, J.A. 1983. Feeding values of cassava tuber and leaf meals. Nutr. Rep. Int., 28: 189-196.

Rayne, S., Mazza, G. 2007. Biological activities of extracts from sumac (Rhus spp.): A review. Plant Food Hum. Nutr., 62: 165-175.

SAS Institute, 2005. SAS/STAT user's guide: version 9. 8th ed. Cary: SAS Institute.

Soad, G. 2010. Center of Search Animal Production. Effect of Moringa oleifera in Diet to Broiler Chicken.

Söğüt, B., İnci, H., Özdemir, G. 2012. Effect of supplemented black seed (Nigella sativa) on growth performance and carcass characteristics of broilers. J. Anim. Vet. Adv., 11: 2480-2484.

Teguia, A., Beynen, A.C. 2005. Alternative Feedstuffs for Broilers in Cameroon. Livestock Research for Rural Development 17(3),

http://www.Irrd.org/Irrd17/3/tegu17034.ht m.

Tekeli, A., Çelik, L., Kutlu, H.R., Gorgulu, M., 2006. Effect of plant extracts on performance, carcass characteristics, digestive system development, intestinal microflora and some blood parameters of broiler chicks; XII European Poultry Conference, Italy, 10-14 Sept. 2006.

Teteh, A., Lawson, E., Tona, K., Decuypere, E., Gbeassor, M. 2013. Moringa oleifera leave: Hydro-alcoholic extract and effects on growth performance of broilers. International Journal of Poultry Science, 12(7): 401-405.

Weiner, M.A. 1994. Herbal Antioxidants in Clinical Practice. J. Orthomolecular Med. 9(3): 167176.

WHO, 1999. Monographs on Selected Medicinal Plants, Vol. 11999 (Geneva).
Yang, W., Shabanov, N.V., Huang, D., Wang, W., Dickinson, R.E., Nemani, R.R., Knyazikhin, Y., Myneni, R.B. 2006. Analysis of leaf area index products from combination of MODIS Terra and Aqua data. Remote Sensing of Environment, 104(2006): 297-312.

Zaidi, M.A., Crow, S.A. 2005. Biologically active traditional medicinal herbs from Balochistan. J. Ethnopharmacol, 96: 331-334.

Zargari, A. 1997. Medicinal Plants. 5th ed. Tehran University Press. p., 561, Iran.

Yang, A., Dunnington, E.A., Siegel, P.B. 1997. Developmental stability in stocks of White Leghorn chickens. Poultry Science, 76: 16321636.

Yew, M.S. 1985. Biosynthesis of ascorbic acid in chick embryos. Experientia, 41: 943-944.

Zhang, H., Elliott, K.E.C., Durojaye, O.A., Fatemi, S.A., Peebles, E.D. 2018. Effects of in ovo administration of L-ascorbic acid on broiler hatchability and its influence on the effects of pre-placement holding time on broiler quality characteristics. Poultry Science, 97(6): 1941-1947. 